\title{
Using a "virtual joint venture" to facilitate the adoption of intermodal transport
}

This is the pre-published version of the text. The final published paper can be found at:

Monios, J., Bergqvist, R. (2015). Using a "virtual joint venture" to facilitate the adoption of intermodal transport. Supply Chain Management: An International Journal. 20 (5): 534-548.

\section{DOI: 10.1108/SCM-02-2015-0051}

\begin{abstract}
Purpose

The supply chain literature discusses various models of supply chain collaboration and integration. When applied to logistics, each has been shown to exhibit different levels of success depending on particular factors. This paper examines a strategic alliance between a large shipper and a freight forwarder to provide an intermodal service to and from the port of Gothenburg.
\end{abstract}

\section{Design/methodology/approach}

The methodology is a single in-depth case study based on action research, interviews and document analysis.

\section{Findings}

According to this innovative model, a new entity is not set up but an open-book basis is established, long-term contracts with other parties are signed, risks and profits are shared, and the shipper makes several investments specific to the service. Thus the benefits of a joint venture are obtained without needing to establish a new organisation and thus sacrifice flexibility and independence.

\section{Research limitations/implications}

A limitation of this study is that it is based on a single case of best practice; it may be difficult to replicate the high levels of trust in other situations. Nevertheless, the evident success of this "virtual joint venture" suggests that some elements are transferable to other cases, and the model may be refined through additional case analysis.

\section{Practical implications}

Results indicate several advantages of this "virtual joint venture" model, including risk sharing, knowledge development, long-term service stability and diversification of activities which all contribute to facilitating the shift of a large customer from road haulage to intermodal transport. Potential challenges mainly relate to contractual complexity.

\section{Originality/value}

This paper identifies an innovative business model for logistics integration that can be used in future in other cases to make modal shift more attractive and successful, which is a key aim of government policy in many countries.

Key words: business model, governance, intermodal transport, logistics, cooperative, collaboration, supply chain management, integration, strategic alliance. 


\section{Introduction}

The supply chain and logistics literature contains many studies of horizontal and vertical integration and collaboration, whether that be in the supply chain or in the provision of logistics services. Supply chain integration is covered more frequently, including integrating the ownership or processes of suppliers, producers, and so on, up and down the vertical supply chain, or horizontal integration or collaboration among partners at the same level (e.g. suppliers joining a cooperative).

A subset of supply chain integration is logistics integration. The customer for the logistics process may have any kind of supply chain strategy, but in this paper the focus is on the provision of logistics services, mostly transport. Building on previous work in the transport literature, where consolidation of flows and the "co-location" of logistics services at transport hubs have been considered ways to support intermodal transport services (Rodrigue et al., 2010; Monios, 2014), this paper examines the potential of a specific type of strategic alliance, a "virtual joint venture", as a governance form for transport services. The focus of this paper is on the business model adopted rather than on the operational aspects of modal shift (for which see Woodburn, 2003; Eng-Larsson and Kohn, 2012; Monios, 2015).

The purpose is to see how this model can address many of the issues of logistics collaboration, such as efficiency gains, knowledge sharing, trust and joint marketing. Against a background where intermodal transport has struggled to compete with road due to inefficiencies stemming partly from transaction costs of a fragmented system, the aim is to explore the potential of a new model that develops new shared services (in this case, rail services) for the benefit of all partners. Little research has been done on direct involvement of customers in managing their own intermodal transport, partly because shippers rarely possess the specialised knowledge and experience to do so. Jensen and Sorkina (2013) explored cases of large shippers managing their own intermodal transport services in-house rather than contracting such services from the market. This paper looks beyond outsourcing a single role or collaborating on an occasional product or service towards a more integrated and extended collaborative planning and consolidation of demand to ensure efficient and fully-loaded intermodal services.

The paper begins with a literature review on supply chain integration and collaboration in order to identify the main drivers and challenges, before proceeding to a discussion of the different types of business models used to manage a variety of strategic alliances in the supply chain. The third part of the literature review narrows the focus from supply chain integration to logistics integration, identifying the kinds of business models generally applied 
in the logistics sector to manage transport and related services. A two-stage conceptual framework is then developed that will be used to identify and explore the characteristics of the virtual joint venture model, first as a more generic case of logistics management, and then proceeding to identify and classify the model as a new form of strategic alliance. The case study and action research methodology is established in section 3, while section 4 presents the empirical research based on a single in-depth case study of a virtual joint venture business model providing intermodal transport services in Sweden. The case study is then analysed to determine the advantages and disadvantages of such a model, before the key features of the model are defined and conclusions drawn on how this model can be used in future to obtain buy-in of large shippers towards modal shift of their traffic from road haulage to intermodal transport.

\section{Literature review}

\subsection{Supply chain management, collaboration and integration}

Supply chain management is a process of coordination between partners in a supply chain, aiming to improve performance for individual companies as well as the supply chain as a whole (Mentzer et al., 2001). In order to manage the supply chain effectively, greater collaboration between partners is required, as it is increasingly accepted that competition is now between supply chains rather than between individual competitors. Supply chain actors must make decisions regarding with whom to collaborate, in what way and to what extent. Supply chain collaboration involves working across organisational boundaries, sharing resources and working cooperatively (Fawcett et al., 2008a).

Supply chain collaboration involves both internal and external dimensions. Internal collaboration refers to coordination of processes or departments, as often the logistics department is not coordinated with the purchasing or marketing department (Gimenez \& Ventura, 2005; Lambert et al., 2008). External collaboration is the process of collaborating with external partners in the supply chain (Stank et al., 2001; Chen et al., 2009).

Several papers have examined the motivations for supply chain collaboration, as well as the potential barriers and facilitators (e.g. Whipple \& Frankel, 2000; Min et al., 2005; Simatupang \& Sridharan, 2005; Cruijssen et al., 2007b; Fawcett et al., 2008a, 2008b; Richey et al., 2010; Guan \& Rehme, 2012). Simatupang \& Sridharan (2005) defined the three key dimensions of collaboration as information sharing, decision synchronisation and incentive alignment, while Whipple \& Frankel (2000) defined the success factors as trust, senior management support, ability to meet performance expectations, clear goals and partner 
compatibility. Fawcett et al. (2006) found that management commitment to supply chain collaboration is lacking, while Daugherty (2011) identified some scepticism in the literature about the ability to achieve true collaboration between partners, as, more than simply outsourcing a specific function, collaboration requires that resources or processes must be integrated (Bowersox et al., 2003).

Fawcett et al. (2008a) derived 25 practices and requirements for supply chain collaboration, summarised into seven categories: management commitment, supply chain mapping and role definition, information sharing and system integration, people management and development, performance measurement, relationship management and trust building, rationalisation and simplification. Similarly, Fawcett et al. (2008b) derived a 30-point framework, based on the top ten benefits (split into customer focus and company focus), barriers (split into interfirm rivalry and managerial complexity) and bridges (split into operations management and people management) to strategic supply chain management. Part of the analysis of the case study will be based on this framework.

Knowledge sharing is an important aspect of collaboration, and will be particularly relevant in relation to improving efficiencies in transport operations as discussed in this paper. However, it takes the investment of time and resources, and risks of losing that investment if withdrawing from the relationship or suffering opportunist behaviour of supply chain partners (Bergqvist, 2007; Gligor \& Holcomb, 2013). Furthermore, organisations need to consider whether the gains from knowledge sharing outweigh the loss or dilution of the competitive advantage derived from that knowledge (Mohr \& Sengupta, 2002; Cheng et al., 2008). In addition, knowledge can be both explicit, thus easily shared, and implicit, which is difficult to convey or capture and requires closer and longer social relationships to exploit (Lang, 2004). Various factors influence knowledge sharing in a supply chain (Spekman et al., 2002; Cheng et al., 2008) and the creation of new knowledge is also often an explicit aim of supply chain cooperation (Wu, 2008).

\subsection{Governance forms for supply chain collaboration and integration}

A continuum stretches from a purely transaction- or market-based approach at one end to a fully integrated ownership model at the other (Williamson, 1975, 1985; Golicic \& Mentzer, 2006; Rinehart et al., 2004). The former are governed by contracts of varying duration, regularly compared with the price and service offered by competitors, whereas integration models can include a merger, an outright purchase of one firm by another or the creation of a new organisation through a joint venture. In between these two extremes lies a variety of 
dynamic hybrid or relational models, which can be summarised into partnerships and alliances (Rinehart et al., 2004; Halldorsson \& Skjott-Larsen, 2006; Lambert et al., 1996, 1999; Humphries et al., 2007; Daugherty, 2011). While a partnership involves a larger or longer commitment than a regular contractual relationship, an alliance takes this arrangement further in a close relationship designed to maximise synergies and achieve a desired strategic outcome (Lambert et al., 1999). The partners in an alliance will likely need to modify their existing logistical setup to increase efficiency under the new alliance model (Frankel et al., 1996); however, formal control mechanisms like contracts and the resulting transaction costs of monitoring, etc. are replaced to a certain degree by trust (Todeva \& Knoke, 2005). The actual form taken by the alliance will depend on several factors, such as the motive, the business environment, industry structure, organisational structure and other drivers (Todeva \& Knoke, 2005).

Market or contractual governance means that relationships are managed through contracts with incentives or penalties. As firms move towards greater collaboration, relational characteristics such as trust, information sharing and mutual decision making become more important. Different mechanisms can be used to coordinate partner relationships, such as monitoring, incentives/hostages and social enforcement based on personal relationships (Wathne \& Heide, 2000). Dyer \& Singh (1998) distinguished between third-party enforcement mechanisms (contracts) and self-enforcing mechanisms (specific investments, financial incentives and trust). Cai et al. (2009) noted the importance of joint problem solving and planning and collaborative communication, while Hernández-Espallardo \& Arcas-Lario (2003) suggested formalisation, participation, input control, behaviour control and output control.

Todeva \& Knoke (2005) developed a 13-stage model of cooperation structure capturing the spectrum from market/contract to hierarchy/integration: market relations, action sets, industry standard groups, subcontractor networks, licensing, franchising, cartels, strategic cooperative agreements, $R \& D$ consortia, cooperatives, equity investments, joint ventures, hierarchical relations. Schmoltzi \& Wallenburg (2011) condensed these hybrid types (and other previous work by Parkhe, 1991; Dussauge \& Garrette, 1997; Klint \& Sjöberg, 2003) into four: verbal agreements, written contracts without equity involvement, minority stake agreements, joint venture agreements. Thus the key element in that formulation is the level of the financial stake taken by the partners. Lambert et al. (1999) identified three types of cooperation in the hybrid range: in the first type, activities and planning are coordinated to a limited degree; in the second, this is developed to integration of some business planning and 
the timescale is lengthened; the third has an indefinite timescale and is considered a "strategic alliance", often with an explicit contractual basis. In that division, it is the level of strategic collaboration that defines the three stages. Similarly, Spekman et al. (1998) consider an evolution from cooperation to coordination to collaboration. Whipple \& Russell (2007) developed a typology of three types of collaborative approaches on a continuum from less to more integrated: transaction management, event management and process management.

Questions have been raised as to whether the supply chain collaboration idealised in the literature is actually happening in reality (Spekman et al., 1998; Min et al., 2005; Fawcett et al., 2006; Sandberg, 2007; Fawcett et al., 2008a). In particular, Sandberg (2007) found that supply chain collaboration was mostly in operations, and was missing a deliberate strategic aspect.

\subsection{Governance forms and logistics business models}

The previous section identified different business models that have been applied to supply chain integration, such as contracts, partnerships, alliances, joint ventures and ownership. These models can apply to the supply chain (for example an exclusive contract between a supplier and a distributor to provide computer components) or can be specifically related to logistics services (for example a joint venture between a 3PL and a rail operator to develop a new rail service).

Mentzer et al. (2004; p.607) described logistics management as "a within-firm function that has cross-function and cross-firm (i.e. boundary-spanning) aspects to it." They go on to say that "logistics is one (if not the major) of the contributions to the benefits of supply chain management" (p.618). As with supply chain collaboration discussed in the preceding sections, logistics arrangements can vary from purely market-based contractual short-term relationships to information sharing through informal trust-based relationships to full integration through ownership. It is common for the transport function to be fully integrated within a 3PL through ownership, while the relationship of interest in this research is that between the shipper and the logistics service provider or freight forwarder. How much information is shared, how is risk allocated, to what extent are decisions truly collaborative? As with supply chain collaboration, a difference has been observed between strategic and operational collaboration (Fugate et al., 2009).

Other logistics decisions influence potential integration, such as the centralisation and relocation of plants and distribution centres, a reduction in the supplier base and a consolidation of the carrier base (Lemoine \& Skjoett-Larsen, 2004; Abrahamsson \& Brege, 
1997). Supply chains are being reconfigured around rationalisation of transport requirements, changing distribution strategies and new hub locations. (Lemoine \& Skjoett-Larsen, 2004).

Bowersox et al. (1989) established a 5-stage model of logistics integration: single transactions, repeated transactions, partnerships, third-party agreements, integrated logistics service agreements. Similar to the integration models described in section 2.2, in this model the partnership stage is when the shipper retains control of planning and management, while a third-party agreement is when the 3PL takes a more direct role in the relationship with a tailored service requiring information sharing, which increases the level of trust required. Finally, an integrated service agreement is where the entire logistics function or at least large parts of it have been outsourced to the 3PL. This will necessarily require a higher level of information integration, possibly through joint ICT, and may also include additional valueadded services as the inventory may in fact be stored at warehouses operated by the 3PL.

Simatupang \& Sridharan (2002) highlighted three aspects of coping with the complex decision making of logistics that can benefit from information sharing among supply chain partners: synchronising the logistics decision horizon for forward-looking planning, consolidating multi-party logistics processes such as matching shippers and carriers or resource availability, and integrating functional scope such as product development, logistics and marketing.

In supply chain management, vertical collaboration involves relationships with supply chain partners up and down the chain. In vertical logistics collaboration, the integration is not along the supply chain but relates to the provision of logistical services, including transport. For instance, a shipper forming a relationship with a 3PL and a rail operator would be an example of vertical collaboration as far as logistics is concerned (Lehtinen \& Bask, 2012). Examples of vertical collaboration in transport and logistics include vendor managed inventory (VMI), efficient customer response (ECR) and collaborative planning, forecasting and replenishment (CPFR) (McCarthy \& Golicic, 2002; Disney \& Towil, 2003; Esper \& Williams, 2003; Skjoett-Larsen et al., 2003; Tuominen, 2004; Cruijssen et al., 2007b).

As with horizontal supply chain collaboration, horizontal collaborations in logistics are likewise with competitors (whether 3PLs or transport providers running services together, or shippers combining loads together to provide economies of scale). A further complication is when a 3PL combines loads for separate customers, which is not actual horizontal collaboration on behalf of the shippers but achieves a similar effect. It could even be described as a horizontal cooperation with a vertical character, for example when a number of shippers adopt similar pallet or container types or use a shared transport hub in order for a 
3PL or transport provider to provide a joint service with lower cost to all users. Mason et al. (2007; p.188) discussed the need to combine "vertical collaboration to reduce costs and improve service levels as well as horizontally with industry partners to better utilise assets and hence to further reduce costs." Hingley et al. (2011) studied the potential of a 4PL to manage horizontal collaboration among large retailers and found reluctance, as control of the supply chain was more important to retailers than improving asset utilisation.

Cruijssen et al. (2007b) noted that horizontal collaboration is common in the maritime and aviation sectors, but less so in landside transport and logistics, due to different characteristics, such as the large number of players and increasing competitiveness and its less capital-intensive nature. Research in the maritime sector has examined how ports can use a variety of mechanisms to coordinate the hinterland transport chain and thus reduce transaction costs (Panayides, 2002; de Langen \& Chouly, 2004; Van der Horst \& de Langen, 2008; Van der Horst \& Van der Lugt, 2009; Lagoudis, et al., 2014). Van der Horst and De Langen (2008) analysed different coordination strategies within competing transport chains that have been adopted in order to attract or secure greater container flows, identifying four kinds: changing the incentive structure of contracts, collective action, partnerships, and vertical integration.

Schmoltzi \& Wallenburg (2011) studied horizontal collaboration among 3PLs, finding that, while almost $60 \%$ of 3PLs in their study operated at least one horizontal partnership with other 3PLs, the failure rate was below 19\%, against an average failure rate for horizontal collaborations in many industries ranging from $50 \%$ to $70 \%$. The authors also found that, while horizontal collaboration might be thought to be based on cost reduction, the primary motivations revealed in their study were service quality improvement and market share enhancement. Other research shows that conflict is more likely in horizontal partnerships than vertical ones because there is direct competition between partners in the same business (Wallenburg \& Raue, 2011). Cruijssen et al. (2007a) found that cooperation on core activities was considered the most attractive reason for horizontal collaboration among 3PLs. Schmoltzi \& Wallenburg (2011) found that the most common function of logistics cooperations was to produce services, which suggests an operational rather than strategic focus, consistent with observations in the literature above. Mortensen \& Lemoine (2008) produced similar findings in an analysis of integration between 3PLs and manufacturers.

Schmoltzi \& Wallenburg (2011) established a six-point typology of logistics cooperation, depicted in Table 1. Their framework is based on horizontal cooperation, which has different characteristics regarding competition between members producing similar product ranges and 
perhaps collaborating on a joint transport service to achieve economies of scale. As the current case is a vertical cooperation, the framework may require some modification in application, but it can serve as a useful structure to identify the features of the virtual joint venture model in logistics.

Table 1. Structural characteristics of logistics cooperation (Schmoltzi \& Wallenburg, 2011)

\begin{tabular}{|c|c|c|c|c|c|c|c|c|}
\hline Contractual scope & $\begin{array}{l}\text { Unwritten } \\
\text { agreement }\end{array}$ & \multicolumn{3}{|c|}{$\begin{array}{l}\text { Contractual } \\
\text { agreement }\end{array}$} & $\begin{array}{r}\text { Minc } \\
\text { ag }\end{array}$ & take & \multicolumn{2}{|c|}{$\begin{array}{c}\text { Joint venture } \\
\text { agreement }\end{array}$} \\
\hline Organisational scope & \multicolumn{4}{|c|}{ Bilateral } & \multicolumn{4}{|c|}{ Multilateral } \\
\hline Functional scope & $\begin{array}{c}\text { Shared } \\
\text { production }\end{array}$ & \multicolumn{3}{|c|}{$\begin{array}{l}\text { Shared marketing } \\
\qquad \text { \& sales }\end{array}$} & \multicolumn{2}{|c|}{ Shared supply } & \multicolumn{2}{|c|}{$\begin{array}{c}\text { Quasi- } \\
\text { concentration }\end{array}$} \\
\hline Geographical scope & Regional & \multicolumn{3}{|c|}{ Nationwide } & Con & ental & \multicolumn{2}{|c|}{ Intercontinental } \\
\hline Service scope & Road & Rail & $S$ & & Air & \multicolumn{2}{|c|}{ Intermodal } & Value-added \\
\hline Resource scope & $\begin{array}{c}\text { No resource } \\
\text { similarity }\end{array}$ & \multicolumn{2}{|c|}{$\begin{array}{c}\text { Similar } \\
\text { market } \\
\text { competence }\end{array}$} & \multicolumn{2}{|c|}{$\begin{array}{c}\text { Similar } \\
\text { market } \\
\text { penetration }\end{array}$} & \multicolumn{2}{|c|}{$\begin{array}{l}\text { Similar } \\
\text { corporate } \\
\text { structure }\end{array}$} & $\begin{array}{l}\text { Extended } \\
\text { resource } \\
\text { similarity }\end{array}$ \\
\hline
\end{tabular}

The key interest will be the relation between functional and service scope. How does the business model enable the partners to share their functional scope in order to provide joint services? Schmoltzi \& Wallenburg (2011) note that there remains no consensus on how to measure cooperation performance, and that is not the goal in this paper as it is too soon to do so, therefore this analysis addresses only the motivations for and structure of the business model.

\subsection{Conceptual framework for use in this paper}

A framework is required for this research that can examine logistics integration; for example, relationships between the partners, degree of integration, which services are integrated and so on. It needs to address the business model (the virtual joint venture, as opposed to other models such as partnerships, etc.), the partners, the activities and the outcomes. It also needs to highlight barriers and facilitators. The first part of the analysis will therefore be based on the benefits, barriers and bridges to successful supply chain management identified by Fawcett et al. (2008b), which summarises the key features identified from the literature in section 2.1. However, a second level of analysis will be required to identify and classify the specific features of the virtual joint venture as applied to logistics, and more specifically as it is applied to facilitating modal shift to intermodal transport. The second stage analysis summarises the key features from the literature in sections 2.2 (governance forms in supply chains) and 2.3 (narrowing the focus to governance 
forms in logistics). This second stage of the analysis will use the Schmoltzi \& Wallenburg (2011) framework to analyse the application of the new governance form to logistics as compared with other business models, and identify its key features so it can be applied in future cases.

\section{Methodology}

According to Yin (2009), a case study approach is appropriate when "how" or "why" questions are being asked, when the investigator does not have control over events (as one might in an experimental methodology) and when the phenomenon being studied cannot be separated from its context. All of these criteria are present in the current research, therefore a case study methodology has been adopted. The case was selected as a unique case, according to Yin's (2009) five-way split of cases (critical, extreme/unique, representative/typical, revelatory and longitudinal). The virtual joint venture model has not been applied in the logistics literature before, therefore this unique case will have much to teach. The case is a jointly developed intermodal transport service operating between the Port of Gothenburg and Jula's central warehouse and distribution centre in Skara via the inland terminal in Falköping, located about $120 \mathrm{~km}$ from the port. ${ }^{1}$

Data were collected through site visits where face-to-face interviews were conducted with representatives from Jula, Schenker Air and Ocean Sweden, the terminal operator in Falköping, Port of Gothenburg, APM Terminals and the municipality of Falköping. The research approach can be characterised as longitudinal since the authors had the opportunity to study this development from point of original idea to the actual implementation. When Jula and Schenker started to discuss an intermodal transport solution, they contacted the authors of this paper, and hence we were given an early opportunity to study the development close up. A total of 21 interviews were conducted during a period of 24 months. Three representatives were interviewed repeatedly: the Logistics Manager Jula AB, the Manager Schenker AB, Division Air \& Ocean and the Development and Logistics Manager of the Municipality of Falköping. During the research process there were substantial interactions and exchange of ideas whereby the research process could also be characterised as action research. Interview data were supplemented by desk research to collect research reports, company reports and brochures and additional industry data. The advantage of personal site visits is that it allows

\footnotetext{
${ }^{1}$ For a comprehensive background to intermodal transport in Sweden, see Bergqvist and Woxenius (2011).
} 
in-depth discussion around the semi-structured interview template, and provides the opportunity to ask additional questions prompted by viewing the operations.

The first step in the analysis was to review the interview and documentary data several times. The data were then organised and reduced by collating evidence in a matrix based on the conceptual framework, according to a three-stage process of data reduction, display and conclusion drawing and verification (Miles and Huberman, 1994). Gaps in the matrix were identified and filled by follow-up emails as well as further data collection via desk research. An iterative process was followed, moving back and forth between data collection, analysis, interpretation and explanation, making use of triangulation to strengthen interpretations.

\section{Case study}

\subsection{Company background}

Jula operates in the DIY segment and focuses on offering professionals an attractive range at low prices. This is possible through large purchases directly from manufacturers all over the world, without intermediaries. The product range has over the years been expanded to include tools, equipment, work clothing, garden products, paints and household items. As of 2014, the company has 73 department stores in three countries (Sweden 41, Norway 21, Poland 11) and 2,400 employees. The 2013 company turnover was $€ 0.5$ billion with profits reaching $€ 57$ million. The company has a strong equity ratio of $48 \%$ (2013). Logistics wise, all flows are coordinated and consolidated at the $100,000 \mathrm{~m}^{2}$ (expansion of additional $50,000 \mathrm{~m}^{2}$ planned to be completed by 2015 ) central warehouse and distribution centre in Skara. The majority of incoming goods to the central warehouse consist of imported containers, mainly from Asia. Schenker Air and Ocean in Sweden hold the Jula key account and coordinate incoming container flows.

\subsection{Initiative}

Jula and Schenker Air and Ocean have had a close collaboration for more than a decade before the discussions regarding a joint intermodal transport service started. The first initial ideas about an intermodal transport service came from the municipality of Falköping who did a pre-study to analyze the possibilities of a rail shuttle between the port of Gothenburg and the intermodal terminal at Falköping. The study proved that there was environmental and cost-saving potential as well as service quality improvement possibilities given that the container flow could be managed much more efficiently by using the terminal in Falköping as a buffer of full containers as well as an empty container depot, meaning that containers could 
be more easily distributed from the terminal in Falköping to exporting companies in the region. At the time, empty containers were often shipped back to the port of Gothenburg and then re-positioned to exporting companies. Jula was experiencing an increasing cost for storage of full containers at the Port of Gothenburg and actually repositioned containers to a nearby container depot in Gothenburg. In order to achieve the identified potential, however, a substantial share of the container flows in the region had to be coordinated and consolidated on the intermodal rail service.

The results of the study were presented to Jula management in 2011, who responded positively to the idea but wanted Schenker to be part of the intermodal transport solution. Another issue for Jula was that they have always enjoyed cheap road haulage because they had the largest container flows in the region and their dominant import flows were attractive to road hauliers when trying to match import and export container flows. The study showed that the intermodal transport solution could be competitive with around 10,000 TEU (twentyfoot equivalent units) per year (cf. Ye, et al., 2014), which was a little less than Jula transported during 2011, even considering the company's steady annual growth of about 10$15 \%$.

It was not until 2012 that Jula's volumes had increased to such a level that they could potentially make up the critical mass for a profitable and stable intermodal transport service. Schenker and Jula established a joint project team to realize the idea in January 2013. After about one year of preparations and investigations, the intermodal transport service was launched, with the first train departing from the container terminal of Port of Gothenburg (Skandiahamnen) for the inland terminal at Falköping on September $4^{\text {th }} 2013$. The service started with a "half train" of 11 wagons, with a capacity of 44 TEU in each direction. As of October 2014, the train capacity was increased to 17 wagons, carrying 68 TEU. The plan is to operate at maximum length as of 2015, i.e. with 21 wagons carrying 84 TEU in each direction. During this time the intermodal transport service has operated 5 times per week.

\subsection{Stakeholders and contracts}

Although Jula's volumes increased so that critical volume was achieved around 2012, there was a long journey ahead to coordinate all stakeholders in order to develop the necessary intermodal terminal facilities and to sign contracts in a synchronized manner and with long enough contract periods to make stakeholders willing to invest. Figure 1 illustrates the complexity in terms of number of agreements and the fact that they had to be coordinated and synchronized. Furthermore, the agreements preceded a long process of trust building in 
order for stakeholders to establish enough confidence and willingness to invest - this refers to both private and public actors.

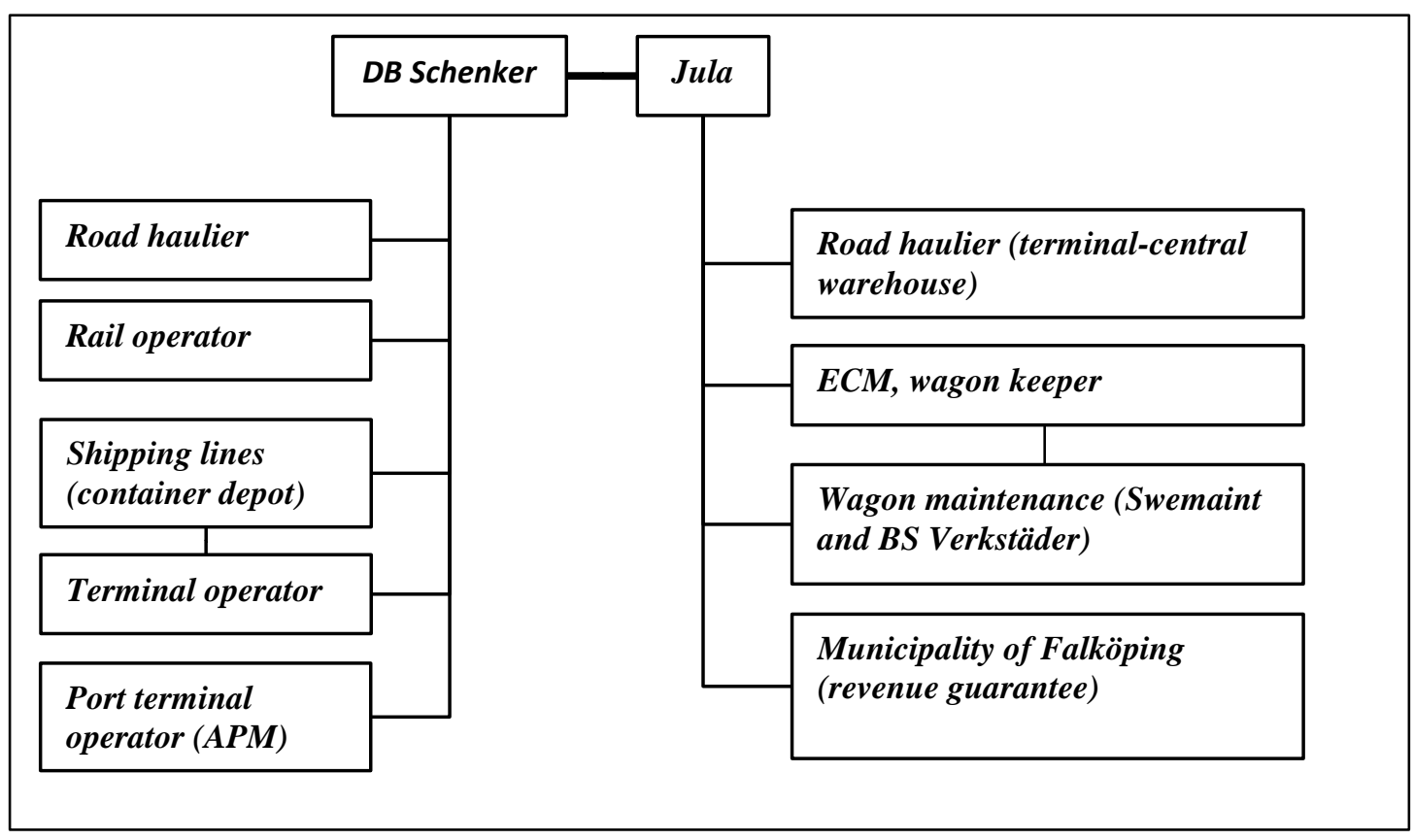

Figure 1. The structure of agreements

The central agreement is that between Jula and Schenker with a focus on defining how risks, investment and benefits are distributed. They operate an open-book agreement with a very high level of transparency and both actors are involved in discussions covering aspects such as pricing, investments, service quality and tendering processes. Both Schenker and Jula have recognised the importance of signing long-term contracts in order to incentivise the terminal operator to invest in the required handling equipment and the municipality to invest in a new terminal adjacent to the old terminal. Hence, Schenker, in the role as control tower, has signed a two-year contract with the rail operator and a five-year contract with the terminal operator (the terminal operator was appointed by the municipality of Falköping through the process of public tendering, cf. Bergqvist and Monios, 2014).

The Swedish rail system has been deregulated since 1988 and there is substantial competition in the rail haulage segment, therefore Schenker and Jula saw it as unnecessary to run the train themselves. In addition, they wanted to explore opportunities for creative suggestions the market may offer. They ran a tender whereby the rail operators were allowed to suggest different solutions where the Gothenburg-Falköping rail shuttle could be combined with other rail solutions and destinations, hence the timetable was not entirely fixed but an indication of favourable time windows were given. The rail operator TM Rail offered the most favourable option and was given a two-year contract. 
In order to enable a long-term investment by the municipality of Falköping in a new intermodal terminal, Jula signed a separate agreement guaranteeing revenues of $€ 250,000$ for the intermodal terminal for a period of five years, starting 1st January 2014. Annual variable terminal rent fees (about $€ 4$ per handled container) are balanced against the guaranteed revenue in case Jula makes an exit within the five year period. This agreement has been crucial in order for the municipality to invest about $€ 2.5$ million in developing a new intermodal terminal. A critical concern in the setup has been to develop the rail shuttle in such a way that Jula and Schenker are flexible and independent so that the sub-contracted rail operator does not gain too much power; this is often the case because they generally own the wagons and control the timetable and the time window (slot) in the container terminal at the seaport. In this case, Schenker has signed an agreement with the port container terminal operator APM Terminals and Jula has invested in container wagons (type Lags071 and SGNSS). Jula becoming a wagon owner means that they had to contract an ECM (Entity in Charge of Maintenance) and a maintenance provider (Swemaint and the local service provider BS Verkstäder). The ECM provides evidence of responsibility and traceability of the maintenance undertaken on freight wagons in accordance with EU Regulation EU/445/2011.

The timetable for the train is not possible to control entirely since a rail traffic certificate is needed which Schenker Air \& Ocean and Jula do not have. Overall, the structure of agreements is rather complex; however, by engaging with all interfaces, a service setup based on transparency and long-term commitment has been achieved which can be argued as necessary in order to develop cost-competitiveness on an intermodal service over such a short distance.

\subsection{Results of the initiative}

In the role as control tower, Schenker takes the responsibility for three main functions: bookings, accounting and monitoring. Besides the operating functions, Schenker also has the responsibility of marketing and sales of the intermodal service to attract other shippers besides Jula. Schenker and Jula continuously discuss market issues since the aim is for Schenker and Jula to attract complementary flows, meaning customers with export flows and largely with the same shipping lines as Jula. This enables effective repositioning of containers and high utilisation rates on the intermodal service. This also means that Schenker does not merely sell capacity on the intermodal service but takes full responsibility for the customers' export and import flows in order to be able to fully coordinate the usage of the service. Other customers that have since joined the intermodal transport service include companies like 
Parker Hannifin, Swedish Match, A Lot of Decoration, Gyllensvaan (supplier of "Billy" bookshelves to IKEA).

For the purpose of effective repositioning of empty containers, Schenker and the inland terminal operator have signed agreements with shipping lines in order for them to set up an empty container depot in Falköping, a process more time consuming and challenging than expected according to the representatives of Schenker. Furthermore, Jula has developed their customs clearance process so that the containers/goods do not need to be cleared until they reach the Jula warehouse in Skara.

Overall, the following benefits have been achieved as compared to the previous roadbased transport service:

- Cost-efficiency

- Traffic safety (less heavy transport on road)

- Environmental performance (about $80 \%$ less emissions of $\mathrm{CO}_{2}$ vs. road transport)

- No waiting times at the Port of Gothenburg

- No port demurrage and no road toll fee

- Imported container stock now closer to Jula's DC/warehouse which creates more even cargo flow into the DC

- Long-term agreements

- Jula is seen as a good benchmark in the Skaraborg region. The new set-up creates opportunities for the entire region and development of intermodal solutions.

- More efficient road haulage through the exemption for long carriage (32 meter $=2 \mathrm{x}$ 40ft).

The final point relates to the project initiated by Jula to develop the possibilities of road haulage of two 40ft containers simultaneously. This has great impact on the cost-efficiency of the intermodal transport solution for Jula as about $70 \%$ of their containers are $40 \mathrm{ft}$ containers and about 30\% 20ft containers (cf. Bergqvist and Behrends, 2011). The current road restrictions only allow for the simultaneous haulage of one $40 \mathrm{ft}$ and one $20 \mathrm{ft}$ container.

Jula started the process of applying for an exemption to the current road restrictions for the transport between the intermodal terminal in Falköping and the central warehouse in Skara in 2012, receiving final approval from the Swedish Transport Agency on 1st December 2014. One of the biggest arguments for the exemption is that it contributes to the efficiency of the intermodal transport solution and, thus, modal shift from road to rail. The road haulage project is one of the reasons why Jula chose to sign their own local road haulage agreement; another decisive factor is the need for a long-term contract in order to persuade the local road haulier to invest in a dozen chassis in order to handle the Jula container flows between the intermodal terminal and Jula's central warehouse. 


\subsection{Future developments, goals and challenges}

Currently, Schenker and the terminal operator focus on developing more agreements with shipping lines in order to increase usage of the container depot at the intermodal terminal at Falköping. Furthermore, Schenker focuses on attracting more shippers to the intermodal transport service. This process is time consuming since shippers are often locked in to existing 1-2 year agreements, but more customers are added continuously. The goal is to reach about 25-30,000 TEU annually (fully loaded containers in total for both directions) within 2-3 years; currently the service handles about 15,000 TEU annually (excluding empty containers).

Another aspect that will benefit the intermodal transport service is the current development of the container terminal in the port of Gothenburg which will allow longer trains (up to $750 \mathrm{~m}$ ) and generate many more time slots for train arrivals. Jula and the municipality of Falkoping have just initiated a project to investigate the opportunities of expanding the intermodal terminal and the transfer yard/marshalling yard in order to be able to handle $750 \mathrm{~m}$ long trains.

The partners are also planning to add additional routes to make better use of the moveable assets (locomotive and wagons). Possible new routes that have been identified relate to incoming flows of input material such as wooden plates to the region but also outgoing flows from the region, e.g. flows to the north of Sweden, Norway and Finland. This will, however, require a new agreement with the traction provider. This new initiative means that Jula and Schenker will gain better utilisation of their wagons and increased profit, enabling Jula to cross-subsidise its own transport costs even further with revenue earned not just on the Gothenburg-Falköping service but on additional routes as well. The sub-contracted rail operator will benefit from an additional contract but will not gain as much as it would were it to operate the new route itself in its own name. Thus the introduction of a vertically integrated joint venture model affects the competitive market place of third-party rail operators competing for traffic. On the other hand, the efficiencies gained from vertical integration (including in this case the terminal infrastructure as Jula's long-term contract with the terminal enables efficient management and investment in the infrastructure) raise questions about the EU directive to separate infrastructure ownership from rail operations.

One important conclusion is that many stakeholders in this case share the need for a continuous improvement process that requires all stakeholders to remain committed to developing the service, value-added activities and infrastructure. The elements of 
entrepreneurship and trust are evident and the cooperative business model is crucial for the construction and maintenance of a sustainable win-win context.

From the perspective of Schenker, they now consider extending the concept to other regions and destinations; however, this requires the same long-term commitment and perspective on mutually beneficial relationships with key stakeholders such as large shippers/customers and transport service providers. This is currently the main challenge since few shippers are used to or wiling to engage in this type of cooperative business model and setup. Schenker hopes that the best practice illustrated by the Jula case can help convince shippers and other stakeholders of the potential associated with this kind of business model, which indeed underlines the need to identify and classify its key features.

\section{Analysis and discussion}

The goal of the analysis is twofold. First, to establish how the innovative business model of the virtual joint venture has achieved the goals of the partners and to identify the key aspects of its implementation. This will be based on the Fawcett et al. (2008b) framework (benefits, barriers and bridges to strategic supply chain collaboration). The second goal is to analyse the application of the innovative governance form to logistics as compared to other business models, in order to construct a generalised model that can be applied in future cases of modal shift from road to intermodal transport. That part of the analysis is based on the sixscope model of Schmoltzi \& Wallenburg (2011).

Findings from the first part of the analysis are presented in Table 2, Table 3 and Table 4. 
Table 2. Case study results: benefits from strategic supply chain collaboration

\begin{tabular}{|c|c|c|}
\hline \multirow{4}{*}{$\begin{array}{l}\text { Customer } \\
\text { focus }\end{array}$} & $\begin{array}{l}\text { Increased customer } \\
\text { responsiveness }\end{array}$ & $\begin{array}{l}\text { - Yes, as the shipper is part of the virtual joint venture providing } \\
\text { the transport service, directing the services and owning the } \\
\text { wagons. }\end{array}$ \\
\hline & $\begin{array}{l}\text { More consistent on- } \\
\text { time delivery }\end{array}$ & $\begin{array}{l}\text { - Yes, by using the inland terminal as a stock buffer for full } \\
\text { containers to feed the DC when required (which is also cheaper } \\
\text { than storing at or near the port) }\end{array}$ \\
\hline & Customer satisfaction & $\begin{array}{l}\text { - Yes, as the shipper is part of the virtual joint venture, directing } \\
\text { the services and owning the wagons. } \\
\text { - All risks and profits shared between shipper and forwarder on } \\
\text { an open-book basis. }\end{array}$ \\
\hline & $\begin{array}{l}\text { Shorter order } \\
\text { fulfilment lead times }\end{array}$ & $\begin{array}{l}\text { - Yes, by using the inland terminal as a stock buffer for full } \\
\text { containers to feed the DC when required (which is also cheaper } \\
\text { than storing at or near the port) }\end{array}$ \\
\hline \multirow{6}{*}{$\begin{array}{l}\text { Company } \\
\text { focus }\end{array}$} & $\begin{array}{l}\text { Reduced purchasing } \\
\text { costs }\end{array}$ & $\begin{array}{l}\text { - As the shipper is part of the virtual joint venture and the rail } \\
\text { traction is sub-contracted, there is no need to pay a profit } \\
\text { margin on top to the operator. Likewise in that the shipper } \\
\text { owns the rail wagons. } \\
\text { - No demurrage costs at the port } \\
\text { - No waiting time at the port therefore reduces haulage costs. } \\
\text { twaulage costs reduced by using longer vehicles transporting } \\
\text { to/from the inland terminal). }\end{array}$ \\
\hline & Better asset utilisation & $\begin{array}{l}\text { - Rail locomotives and wagons are used more efficiently because } \\
\text { the shipper is involved in the planning for the service to keep it } \\
\text { as full as possible. } \\
\text { - As the shipper owns the wagons they are the right type for their } \\
\text { needs and always available. } \\
\text { - Better use of empty containers due to local empty depot. }\end{array}$ \\
\hline & $\begin{array}{l}\text { Ability to handle } \\
\text { unexpected events }\end{array}$ & $\begin{array}{l}\text { - Long-term contracts ensure commitment, such as Jula } \\
\text { committing to pay the inland terminal fees for five years. } \\
\text { - Owning the wagons inhouse reduces problems with } \\
\text { unavailability or maintenance scheduling. }\end{array}$ \\
\hline & $\begin{array}{l}\text { Reduced inventory } \\
\text { costs }\end{array}$ & - Yes, by using the inland terminal as a stock buffer. \\
\hline & Firm productivity & $\begin{array}{l}\text { - The productivity of the intermodal service was higher than a } \\
\text { normal third-party service because of many reasons: it was } \\
\text { underwritten by a large shipper (Jula), the shipper bought the } \\
\text { wagons (reducing hiring costs and uncertainties), the rail } \\
\text { traction was selected by tender (thus ensuring low cost as well } \\
\text { as stability), and Schenker has the responsibility to attract new } \\
\text { users to the service. In addition, the inland terminal was used } \\
\text { as a stock buffer. }\end{array}$ \\
\hline & $\begin{array}{l}\text { Reduced overall } \\
\text { product cost }\end{array}$ & - Yes, due to the efficiencies described above. \\
\hline
\end{tabular}


Table 3. Case study results: barriers to strategic supply chain collaboration

\begin{tabular}{|c|c|c|}
\hline \multirow{4}{*}{$\begin{array}{l}\text { Interfirm } \\
\text { rivalry }\end{array}$} & $\begin{array}{l}\text { Inadequate information } \\
\text { sharing }\end{array}$ & $\begin{array}{l}\text { - This may be a barrier to replicating the concept elsewhere but } \\
\text { in this project it was overcome by creating the virtual joint } \\
\text { venture based on an open-book arrangement sharing all } \\
\text { information about the service (stock flows, timings, etc.) as } \\
\text { well as sharing all risks and profits. }\end{array}$ \\
\hline & $\begin{array}{l}\text { Inconsistent operating } \\
\text { goals }\end{array}$ & - As above. \\
\hline & $\begin{array}{l}\text { Lack of willingness to } \\
\text { share risks and rewards }\end{array}$ & $\begin{array}{l}\text { - The open-book basis was key to removing the need for Jula } \\
\text { to pay a margin on top of the cost price. }\end{array}$ \\
\hline & $\begin{array}{l}\text { Lack of willingness to } \\
\text { share information }\end{array}$ & - As above. \\
\hline \multirow{6}{*}{$\begin{array}{l}\text { Managerial } \\
\text { complexity }\end{array}$} & $\begin{array}{l}\text { Lack of alliance } \\
\text { guidelines }\end{array}$ & $\begin{array}{l}\text { - This could have been a problem in principle but was } \\
\text { overcome in this case by having already built trust by Jula } \\
\text { and Schenker working together for many years before they } \\
\text { established the virtual joint venture. } \\
\text { - There were also the other parties involved such as the } \\
\text { municipality and the inland terminal, which all had to have } \\
\text { explicit contracts and guarantees with clear roles and risks. } \\
\text { - However, the classification of the key features of the model } \\
\text { in this paper will facilitate the use of clear guidelines in } \\
\text { future application. }\end{array}$ \\
\hline & $\begin{array}{l}\text { Process poorly appraised } \\
\text { in terms of cost }\end{array}$ & $\begin{array}{l}\text { - This was not a problem in this case, because the process took } \\
\text { a long time to prepare, based on feasibility studies and many } \\
\text { years of experience by all partners who were able to specify } \\
\text { the costs involved in accurate detail. }\end{array}$ \\
\hline & Non-aligned measures & $\begin{array}{l}\text { - The roles of each partner and the measures introduced and } \\
\text { monitored were all clearly established. }\end{array}$ \\
\hline & Organisation boundaries & $\begin{array}{l}\text { - These were clearly established by constructing the virtual } \\
\text { joint venture structure, as well as the set of contracts between } \\
\text { all the other parties. }\end{array}$ \\
\hline & $\begin{array}{l}\text { Measuring supply chain } \\
\text { contribution }\end{array}$ & $\begin{array}{l}\text { - Roles and responsibilities were clearly established. For } \\
\text { example, Jula purchased the wagons and Schenker was } \\
\text { responsible for marketing and sales to attract additional } \\
\text { shippers to the intermodal service. }\end{array}$ \\
\hline & $\begin{array}{l}\text { Measuring customer } \\
\text { demand }\end{array}$ & $\begin{array}{l}\text { - This was done in a feasibility study initiated by the } \\
\text { municipality (and owner of the inland terminal), and the core } \\
\text { demand provided by Jula underpinned the service. }\end{array}$ \\
\hline
\end{tabular}


Table 4. Case study results: bridges to strategic supply chain collaboration

\begin{tabular}{|c|c|c|}
\hline \multirow{4}{*}{$\begin{array}{l}\text { Operations, } \\
\text { process \& } \\
\text { supply } \\
\text { management }\end{array}$} & $\begin{array}{l}\text { Accurate comprehensive } \\
\text { measures }\end{array}$ & $\begin{array}{l}\text { - This derives from overcoming the potential barriers relating } \\
\text { to shared goals of partners and agreement on using the same } \\
\text { metrics and processes for monitoring the process and } \\
\text { measuring its success. As the former elements were all in } \\
\text { place, this bridge can be viewed as being successfully in } \\
\text { place. }\end{array}$ \\
\hline & $\begin{array}{l}\text { Supplier alignment and } \\
\text { rationalisation }\end{array}$ & $\begin{array}{l}\text { - By setting up a virtual joint venture between a large shipper } \\
\text { and a dedicated forwarder and then sub-contracting the rail } \\
\text { traction for two years, the supply of the service is stabilised. } \\
\text { It is also rationalised by using competition for the market } \\
\text { (tender) rather than direct on-rail competition which can } \\
\text { increase transaction costs and reduce asset utilisation by } \\
\text { changing operator and equipment. } \\
\text { - Owning their own wagons also reduces transaction costs and } \\
\text { obviates the need to pay a profit margin to the operator for } \\
\text { wagon provision. }\end{array}$ \\
\hline & $\begin{array}{l}\text { Effective use of pilot } \\
\text { projects }\end{array}$ & $\begin{array}{l}\text { - It is difficult to run a pilot project in the provision of rail } \\
\text { services due to the long planning time and high expense } \\
\text { involved. But (see next point), the project was planned in } \\
\text { great detail before commencing. }\end{array}$ \\
\hline & $\begin{array}{l}\text { Process documentation } \\
\text { and ownership }\end{array}$ & $\begin{array}{l}\text { - The project was prepared in detail with feasibility studies, } \\
\text { based on many contracts between partners and underwritten } \\
\text { with the high container flows of Jula therefore the service } \\
\text { was established with a clear process. }\end{array}$ \\
\hline \multirow{6}{*}{$\begin{array}{l}\text { People } \\
\text { management }\end{array}$} & $\begin{array}{l}\text { Managerial and } \\
\text { employee support }\end{array}$ & $\begin{array}{l}\text { - The personnel directly involved were for the most part } \\
\text { already known to each other therefore already had the } \\
\text { seniority to pursue the project, therefore new managerial } \\
\text { support was not required in this instance. However, of course } \\
\text { the virtual joint venture had to be approved by senior } \\
\text { management at both organisations. }\end{array}$ \\
\hline & $\begin{array}{l}\text { Open information } \\
\text { sharing }\end{array}$ & $\begin{array}{l}\text { Open-book basis and sharing of risk and profit between } \\
\text { virtual joint venture members Jula and Schenker. }\end{array}$ \\
\hline & Trust-based alliances & $\begin{array}{l}\text { - Staff had pre-existing personal relationships with each other } \\
\text { for many years. }\end{array}$ \\
\hline & $\begin{array}{l}\text { Cross-trained } \\
\text { experienced managers }\end{array}$ & $\begin{array}{l}\text { - As the two organisations had already worked together for } \\
\text { many years, there was a good level of cross-training and } \\
\text { knowledge sharing already in place. }\end{array}$ \\
\hline & $\begin{array}{l}\text { Supply chain education } \\
\text { and training }\end{array}$ & $\begin{array}{l}\text { - Additional formal education was not required, beyond } \\
\text { experience developed in the role. }\end{array}$ \\
\hline & $\begin{array}{l}\text { Using chain advisory } \\
\text { councils }\end{array}$ & $\begin{array}{l}\text { - The municipality as initial instigator of the scheme and } \\
\text { investor in the terminal was able to provide advice and } \\
\text { integration with the business community and other relevant } \\
\text { chambers and associations. }\end{array}$ \\
\hline
\end{tabular}


The particular aim of the Fawcett et al. (2008b) framework is its focus on the strategic aspect of collaboration. This focus is suitable for application to the virtual joint venture in this case, whereby it is a long-term strategic venture rather than purely a cost-saving measure. Indeed, the literature review suggests that supply chain collaboration tends to be more operational than strategic (Sandberg, 2007; Fugate et al., 2009); in this case, a deliberate strategic aspect was clearly revealed. By the shipper including transport in its core business, it has not only secured this initial route but expanded the scope of the transport service to the point where the firm is beginning to have its own transport costs cross-subsidised by other users. The application of the framework nevertheless reveals many practical benefits, such as savings in cost and time by taking direct control of the service rather than the usual thirdparty contractual handling of transport services. Responsiveness was increased and lead times reduced by using the inland terminal as a stock buffer for incoming containers, rather than using the port. The literature also showed that other logistics decisions influence the potential for integration, such as the centralisation and relocation of plants and distribution centres, a reduction in the supplier base and a consolidation of the carrier base (Lemoine \& SkjoettLarsen, 2004; Abrahamsson \& Brege, 1997). In this case, the shipper's use of one large distribution centre and one port allows flows to be consolidated on a single rail link.

The potential barriers identified by Fawcett et al. (2008b) derive from interfirm rivalry and managerial complexity. None of these potential barriers were observed in this case, which is an unexpected result that suggests the model adopted by the partners was very effective. On the other hand, it is recognised that this is something of a unique situation because the two firms have been working together for many years and a high level of personal trust was already established, which is not always possible to replicate. There is also some risk of response bias from the interviews producing a hesitation to reveal negative aspects of the business model. However, even given this positive background, in order to form the virtual joint venture the partners needed to take a further step by investing significant sums in equipment, signing various contracts with other organisations, offering a financial guarantee to the inland terminal and taking a large risk with the reliability of their incoming shipments. Jula is a relatively large company and they possess the leverage to obtain the cheapest road haulage rates, so they would normally have less motivation to take the risk of switching their flows to intermodal transport. Therefore, perhaps it is unsurprising that they have only done so via a method whereby they retain a large share of control. Comparisons can be made to the use of intermodal transport by UK retailer Tesco, whereby 
the retailer purchases whole trains from the rail operator in order to be able to control the timings and rely less on other organisations (Monios, 2015).

Most interesting in terms of seeking to replicate this case in future, the bridges enabling successful collaboration were trust and people management (as already discussed), but also the rationalisation and alignment of processes, as the literature showed the importance of decision synchronisation (Simatupang \& Sridharan, 2005) and joint product development (Simatupang \& Sridharan, 2002). This is why it is essential to ensure direct participation of the shipper, because it forges a close relationship between the parties and also allows flow management to be managed directly in a highly responsive manner. This therefore increases partner compatibility (Whipple \& Frankel, 2000). As discussed by Frankel et al. (1996), partners in a strategic alliance will likely need to modify their existing logistical setup to increase efficiency under the new model; however, formal control mechanisms like contracts and the resulting transaction costs of monitoring are ideally replaced to a certain degree by trust, as also noted by Todeva \& Knoke (2005). The actual form taken by the alliance will depend on several factors, such as the motive, the business environment, industry structure, organisational structure and other drivers specific to the local context. The analysis in the framework showed that indeed the partners did need to modify their existing logistics setup to fit the new model; however, it is important to observe that the shipper Jula wanted to retain the involvement of their haulier Schenker in the intermodal transport solution. This is a common issue when persuading a large shipper to change modes to rail for a particular route as they will still be relying heavily on their road haulier or freight forwarder for most of their traffic and will be wary of damaging that relationship.

The next section of the analysis is to identify and classify the type of business model adopted by Jula and Schenker. It is not full integration therefore it will be one of the hybrid models of partnership and alliance identified in the literature review (see section 2.2). The question to be determined is whether it is a joint venture or a less integrated model such as equity investment or strategic cooperative agreement.

A joint venture requires actually establishing a new organisation which is not the case here. Indeed, the service is still run by Schenker for Jula as before. The difference is that it is open book so both companies know if the service made a profit or loss and they have agreed to share the profit/loss. The other differences are that Jula guarantees a certain volume to Schenker and a certain income to the terminal, and Jula has purchased rail wagons. So Jula has not made equity investments in a joint venture organisation, but it has made investments related to setting up the service. Specific investments were described by Dyer \& Singh (1998) 
as a self-enforcing mechanism for supply chain collaboration. This therefore represents an innovative way to set up a new intermodal transport service that achieves greater buy-in from the shipper, and this could be a new business model for actors to adopt that gets buy-in from both sides. It is virtual in the sense that they did not actually set up a new organisation (which would make it a joint venture) but they act as if they have. Comparisons can be made to Porter's (1998; p.80) discussion of clusters: “A cluster allows each member to benefit as if it had greater scale or as if it had joined with others, without sacrificing its flexibility." Therefore, the specific kind of strategic alliance used by the partners could be described as a contractual third-party relationship to operate a service but with increased buy-in (literally, in this case) from the shipper, leading it closer to being a joint venture. So they act as if it is a joint venture, but without sacrificing flexibility or independence. So the service can be defined as a "virtual joint venture".

The next step is to identify the specific aspects of applying the virtual joint venture in logistics as opposed to other sectors, which is done by using the six-scope model of Schmoltzi \& Wallenburg (2011), presented in Table 5. 
Table 5. Case results according to the six-scope model

\begin{tabular}{|c|c|c|}
\hline Scope & $\begin{array}{c}\text { Case findings classified } \\
\text { according to Schmoltzi } \\
\text { \& Wallenburg (2011) } \\
\text { terminology } \\
\end{array}$ & Case findings description \\
\hline Contractual & $\begin{array}{l}\text { Elements of contractual } \\
\text { agreement, minority stake } \\
\text { agreement and joint } \\
\text { venture agreement }\end{array}$ & $\begin{array}{l}\text { It is not a new entity but a "virtual" joint venture, } \\
\text { based on several contractual agreements (e.g. with } \\
\text { the terminal, the municipality, the rail traction } \\
\text { provider) as well as significant investments and a } \\
\text { high level of trust between Jula and Schenker. }\end{array}$ \\
\hline Organisational & Multilateral & $\begin{array}{l}\text { Two partners (Jula \& Schenker) with additional } \\
\text { cooperation and contracts with the intermodal } \\
\text { terminal owner and a sub-contracting relationship } \\
\text { with the rail operator. }\end{array}$ \\
\hline Functional & Quasi-concentration & $\begin{array}{l}\text { The virtual joint venture agreement includes supply } \\
\text { of assets (wagons), production of transport services, } \\
\text { joint sales and marketing. High level of functional } \\
\text { integration and development of new services. }\end{array}$ \\
\hline Geographical & Regional & Started as a single route but now expanding. \\
\hline Service & Intermodal & $\begin{array}{l}\text { The core product is a single rail route; however, } \\
\text { Schenker provides pre- and end-haulage and the } \\
\text { terminal operator is also involved in stock buffering } \\
\text { and empty container management, and they also } \\
\text { obtained legal permission to use longer trucks for } \\
\text { the terminal haulage, so overall it can be described } \\
\text { as an intermodal product. }\end{array}$ \\
\hline Resource & $\begin{array}{l}\text { Schmoltzi \& Wallenburg } \\
\text { (2011) focus on } \\
\text { horizontal integration } \\
\text { therefore their categories } \\
\text { are not directly relevant to } \\
\text { this case. }\end{array}$ & $\begin{array}{l}\text { As with most vertical integration, a resource } \\
\text { complementarity exists as each partner needs the } \\
\text { other to provide their part of the service. What is } \\
\text { unique in this case is the blend of asset ownership, } \\
\text { service provision, contracts, other investment and } \\
\text { long time scale. }\end{array}$ \\
\hline
\end{tabular}

The results in the table reveal the key differences between the "virtual joint venture" business model and a regular joint venture or a less integrated partnership or alliance. The case exhibited a high level of functional integration between the partners, reflected in the longer contracts, the investment of the shipper in transport assets and the joint marketing and sales (often an overlooked area of contention in intermodal transport - cf. Bergqvist \& Monios, 2014). Perhaps the most interesting aspect is the sixth scope, but as Schmoltzi and Wallenburg (2011) focus on horizontal integration, their categories are not relevant here and must be derived directly from the case. As with most vertical integration, a resource complementarity exists as each partner needs the other to provide their part of the service. What is unique in this case is the blend of asset ownership (sub-contracted rail operator 
provides the loco, Jula provides the wagons), service provision (Schenker books the rail operator and manages the service while Jula underwrites it with a certain level of cargo backed by a financial guarantee to the terminal), contracts (many contracts with the inland terminal, the municipality, the port terminal operator and others) other investment (terminal owner invested significantly in the terminal) and long time scale (reasonably long contracts were signed by all partners). The result is greater levels of many of the most important attributes from the Fawcett et al. (2008b) model such as trust, learning and continuous improvement, information sharing, willingness to take risks and an increased alignment of goals, all of which underpin successful supply chain management, but are particularly important in the difficult task of encouraging shippers to change modes from road to intermodal transport.

\section{Conclusion}

The supply chain literature discusses various business models adopted to manage relationships between stakeholders, such as partnerships, alliances, joint ventures or integration through mergers and acquisitions. Each involves varying levels of integration and collaboration, as well as risk and reward. When applied to logistics, each has been shown to exhibit different levels of success depending on particular factors.

This paper examined a strategic alliance between a large shipper and a freight forwarder to provide an intermodal service to and from the port of Gothenburg. According to this innovative model, a new entity is not set up (as it would be with a joint venture) but an openbook basis is established, long-term contracts with other parties are signed, risks and profits are shared, and several investments specific to the service were made, including new wagon assets by the shipper Jula and new terminal facilities by the terminal owner. This model therefore goes beyond a usual strategic alliance because of the purchase of new assets and other investments in the service, which move the model closer to being a joint venture. Thus the benefits of a joint venture are obtained while the forwarder provides what is nevertheless still a third-party contractual service. What is particularly interesting is that the forwarder Schenker is considering expanding the service to another route serving different shippers with the use of Jula's wagons and the profits from this service will cross-subsidise the original route. Therefore the two partners are acting like a new entity, even though the actual service will be run by Schenker. The other difference is that, unlike a typical joint venture which is time-limited, this partnership is an ongoing strategic initiative. 
By analysing the case study according to a 30-point framework of benefits, barriers and bridges to successful supply chain management, it was shown that this model utilised many of the benefits relating to trust and commitment to overcome most of the potential barriers. In addition, by the direct involvement of the shipper in product development and decision synchronisation, the benefits achieved went beyond just cost reduction to include greater strategic control over the service and future development possibilities.

Using hierarchies of integration from the literature (from market-based to full integration), the innovative model can be classified as a unique kind of strategic alliance that moves towards a joint venture due to the significant investments, high level of functional integration and especially the new service development. The model was therefore classified as a "virtual joint venture", whereby the partners obtain the benefits as if they were in a joint venture without needing to establish a new organisation and thus sacrifice flexibility and independence. Although in its early stages of development, results indicate several advantages of this model, including risk sharing, knowledge development, long-term service stability and diversification of activities which all contribute to facilitating the shift of the large customer from road haulage to intermodal transport. Potential challenges mainly relate to contractual and relationship complexity, but the features of the model identified in this paper can be used in future in other cases to make modal shift more attractive and successful.

One limitation of this study is that it was based on one case, and it may be difficult to replicate the high levels of trust in other situations, thus further study is required of similarly integrated alliances used in logistics. Having said that, the literature shows that high levels of trust are essential for all partnerships and alliances, even less integrated models than the one examined in this paper. The key aspect of the new model is an organisation changing its functional scope, which has enabled the high level of process integration beyond that achievable by regular outsourcing or even through an open-book outsourcing model. This suggests that aspects of the business model can be generalizable to other collaborative partnerships for producing intermodal transport services. The case shows that a shipper can invest in assets unrelated to their core business (in this case transport assets, i.e. rail wagons) and use the fees paid by other users of the service to cross-subsidize their own transport costs. The goal of identifying and classifying a best practice business model is to demonstrate that other cases can achieve similar results if willing to alter their logistics setup and modify their view on what is their core business. 


\section{Acknowledgements}

The authors would like to thank the company representatives who shared their time and knowledge with us throughout the course of this research. The research for this paper was undertaken with the financial support of the GreCOR project funded by the European Union through the ERDF Interreg IVB programme, The Swedish Transport Administration and The Sustainable Transport Initiative financed by the Swedish Government.

\section{References}

Abrahamsson, M., Brege, S., 1997. Structural changes in the supply chain. The International Journal of Logistics Management. 8 (1): 35-44.

Bergqvist, R. (2007) Studies in Regional Logistics - The Context of Public-Private Collaboration and Road-Rail Intermodality, Logistics and Transport Research Group, Department of Business Administration, BAS Publishing, Göteborg, Sweden.

Bergqvist, R. and Behrends, S. (2011) Assessing the Effects of Longer Vehicles: The Case of Pre- and Post-haulage in Intermodal Transport Chains, Transport Reviews, V. 31, No 5, pp. 591-602.

Bergqvist, R. and Monios, J. (2014) “The role of contracts in achieving effective governance of intermodal terminals", Journal of World Review of Intermodal Transportation Research (WRITR), Vol. 5, No. 1, pp. 18-38.

Bergqvist, R. and Woxenius, J. (2011) “The development of hinterland transport by rail - the story of Scandinavia and the Port of Gothenburg", Journal of Interdisciplinary Economics, Vol. 23, No. 2, pp. 161-177.

Bowersox, D.J., Closs, D.J. and Stank, T.P. (2003), "How to master cross-enterprise collaboration", Supply Chain Management Review, Vol. 7 No. 4, pp. 18-27.

Bowersox, D. J., Daugherty, P. J., Dröge, C. L., Rogers, D. S., Wardlow, D. L. (1989). Leading Edge Logistics: Competitive Positioning for the 1990s. Oak Brook, IL: Council of Logistics Management.

Cai, S., Yang, Z., Hu, Z. (2009). Exploring the governance mechanisms of quasi-integration in buyer-supplier relationships. Journal of Business Research. 62 (6): 660-666.

Chen, H., Daugherty, P. J., Roath, A. S. 2009. Defining and operationalizing supply chain process integration. Journal of Business Logistics. 30 (1): 63-84.

Cheng, J-H., Yeh, C-H., Tu, C-W. 2008. Trust and knowledge sharing in green supply chains. Supply chain management: an international journal. 13 (4): 283-295. 
Cruijssen, F., Cools, M., Dullaert, W. 2007. Horizontal cooperation in logistics: opportunities and impediments. Transportation Research Part E. 43 (2): 129-142.

Cruijssen, F., Dullaert, W., Fleuren, H. 2007. Horizontal cooperation in transport and logistics: a literature review. Transportation Journal. 46 (3): 22-39.

Daugherty, P. J. (2011). Review of logistics and supply chain relationship literature and suggested research agenda. International Journal of Physical Distribution and Logistics Management. 41(1): 16-31.

De Langen, P. W., Chouly, A., 2004. Hinterland access regimes in seaports. European Journal of Transport and Infrastructure Research. 4 (4): 361-80.

Disney, S.M. and Towill, D.R., 2003. The effect of VMI dynamics on the bullwhip effect in supply chains, International Journal of Production Economics, 85 (2): 199-215.

Dussauge, P., Garrette, B. (1997). Anticipating the evolutions and outcomes of strategic alliances between rival firms. International Studies of Management \& Organization. 27: 104-26.

Dyer, J. H., Singh, H. 1998. The relational view: cooperative strategy and sources of interorganizational competitive advantage. Academy of Management Review. 23 (4): 660-679.

Eng-Larsson, F. and Kohn, C. (2012), “Modal shift for greener logistics - the shipper's perspective", International Journal of Physical Distribution and Logistics Management, Vol. 42 No. 1, pp. 36-59.

Esper, T. L., Williams, L. R. 2003. The value of collaborative transportation management (CTM): its relationship to CPFR and information technology. Transportation Journal. 42 (4): 55-65.

Fawcett, S. E., Magnan, G. M., McCarter, M. W. 2008. A three-stage implementation model for supply chain collaboration. Journal of Business Logistics. 29 (1): 93-112.

Fawcett, S. E., Magnan, G. M., McCarter, M. W. 2008. Benefits, barriers and bridges to effective supply chain management. Supply Chain Management: An International Journal. 13 (1) : 35-48.

Fawcett, S. E., Ogden, J. A., Magnan, G. M., Cooper, M. B. 2006. Organizational commitment and governance for supply chain success. International Journal of Physical Distribution \& Logistics Management. 36 (1): 22-35.

Frankel, R., Whipple, J.S. and Frayer, D.J. (1996), "Formal versus informal contracts: achieving alliance success", International Journal of Physical Distribution \& Logistics Management, Vol. 26 No. 3, pp. 47-63. 
Fugate, B. S., Davis-Sramek, B., Goldsby, T. J. 2009. Operational collaboration between shippers and carriers in the transportation industry. The International Journal of Logistics Management. 20 (3): 425-447.

Gimenez, C., Ventura, E. 2005. Logistics-production, logistics-marketing and external integration. International Journal of Operations \& Production Management. 25 (1): 2038.

Gligor, D. M., Holcomb, M. 2013. The role of personal relationships in supply chains: An exploration of buyers and suppliers of logistics services. International Journal of Logistics Management. 24 (3): 328-355.

Golicic, S. L., Mentzer, J. T., 2006. Am empirical examination of relationship magnitude. Journal of Business Logistics. 27 (1): 81-108.

Guan, W., Rehme, J. 2012. Vertical integration in supply chains: driving forces and consequences for a manufacturer's downstream integration. Supply Chain Management : An International Journal. 17 (2) : 187-201.

Halldórsson. A., Skjøtt-Larsen, T. 2006. Dynamics of relationship governance in TPL arrangements - a dyadic perspective. International Journal of Physical Distribution \& Logistics Management. 36 (7): 490-506.

Hernández-Espallardo, M., Rodríguez-Orejuela, A., Sánchez-Pérez, M. 2010. Interorganizational governance, learning and performance in supply chains. Supply Chain Management: An International Journal. 15 (2): 101-114.

Hingley, M, Lindgreen, A., Grant, D. B., Kane, C., 2011. Using fourth-party logistics management to improve horizontal collaboration among grocery retailers. Supply Chain Management: An International Journal. 16 (5): 316-327

Humphries, A. S., Towriss, J., Wilding, R. 2007. A taxonomy of highly interdependent supply chain relationships. The International Journal of Logistics Management. 18 (3): 385-401.

Jensen, A., Sorkina, E. 2013. Customer managed intermodal transport solutions: why, how, for whom? World Review of Intermodal Transportation Research. 4 (1): 37-54.

Klint, M. B., Sjöberg, U. 2003. Towards a comprehensive SCP-model for analysing strategic networks/alliances. International Journal of Physical Distribution \& Logistics Management. 33 (5): 408-426.

Lagoudis, I.N, Rice, J.B. Jr and Salminen, J.B., 2014. Port Investment Strategies Under Uncertainty: The Case of a Southeast Asian Multipurpose Port, The Asian Journal of Shipping and Logistics, 3 (3): 299-319. 
Lambert, Douglas M., Margaret A. Emmelhainz, and John T. Gardner (1996), "Developing and Implementing Supply Chain Partnerships," The International Journal of Logistics Management, Vol. 7, No. 2, pp. 1-17.

Lambert, D. M., Emmelhainz, M. A, Gardner, J. T. (1999), "Building Successful Logistics Partnerships," Journal of Business Logistics, Vol. 20, No. 1, pp. 165-181.

Lambert, D. M., García-Dastugue, S. J., Croxton, K. L. 2008. The role of logistics managers in the cross-functional implementation of supply chain management. Journal of Business Logistics. 29 (1): 113-132.

Lang, J. C. (2004), "Social context and social capital and enablers of knowledge integration", Journal of Knowledge Management, Vol. 8 No. 3, pp. 89-105.

Lehtinan, J., Bask, A. H. 2012. Analysis of business models for potential 3Mode transport corridor. Journal of Transport Geography. 22 (1): 96-108.

Lemoine, O. W., Skjoett-Larsen. (2004). Reconfigurations of supply chains and implications for transport; a Danish study. International Journal of Physical Distribution and Logistics Management. 34 (10): 793-810.

Mason, R., Lalwani, C., Boughton, R. (2007). Combining vertical and horizontal collaboration for transport optimisation. Supply Chain Management: An International Journal. 12 (3): 187-199.

McCarthy, T. M., Golicic, S. L. 2002. Implementing collaborative forecasting to improve supply chain performance. International Journal of Physical Distribution and Logistics Management. 32 (6): 431-454.

Mentzner, J. T., Min, S., Bobbitt, L. M. 2004. Toward a unified theory of logistics. International Journal of Physical Distribution and Logistics Management. 34 (8): 606627.

Menzter, J. T., DeWitt, W., Keebler, J. S., Min, S., Nix, N. W., Smith, C. D., Zacharia, Z. G. 2001. "What is supply chain management?", in Menzter, J. T. (ed.). Supply Chain Management. Sage: Thousand Oaks, CA. pp.347-369.

Miles, M. B. and Huberman, A. M. (1994), Qualitative Data Analysis, Sage, Thousand Oaks, CA.

Min, S., Roath, A. S., Daugherty, P. J., Genchev, S. E., Chen, H., Arndt, A. D., Richey, R. G. 2005. Supply chain collaboration: what's happening? The International Journal of Logistics Management. 16 (2): 237-256. 
Mohr, J. J. and Sengupta, S. (2002), "Managing the paradox of inter-firm learning: the role of governance mechanisms", Journal of Business and Industrial Marketing, Vol.17 No.4, pp. 282-301.

Monios, J. (2014). Institutional challenges to intermodal transport and logistics. Ashgate: London.

Monios, J. (2015). Integrating intermodal transport with logistics: a case study of the UK retail sector. Transportation Planning and Technology. 38 (3): 1-28.

Mortensen, O., Lemoine, O. W. 2008. Integration between manufacturers and third party logistics providers? International Journal of Operations \& Production Management. 28 (4): 331-359.

Panayides, P. M. 2002. Economic organisation of intermodal transport. Transport Reviews. 22 (4): 401-414.

Parkhe, A. 1991. Interfirm diversity, organizational learning, and longevity in global strategic alliances. Journal of International Business Studies. 22 (4): 579-601.

Porter, M. E. (1998). Clusters and the new economics of competition. Harvard Business Review. Nov-Dec 1998.

Richey, R. G., Roath, A. S., Whipple, J. M., Fawcett, S. E. 2010. Exploring a governance theory of supply chain management: barriers and facilitators to integration. Journal of Business Logistics. 31 (1): 237-256.

Rinehart, L.M., Eckert, J.A., Handfield, R.B., Page, T.J. Jr and Atkin, T. (2004), “An assessment of supplier-customer relationships", Journal of Business Logistics, Vol. 25 No. 1, pp. 25-61.

Rodrigue, J-P., Debrie, J., Fremont, A., Gouvernal, E., 2010. Functions and actors of inland ports: European and North American dynamics. Journal of Transport Geography. 18 (4): 519-529.

Sandberg, E. 2007. Logistics collaboration in supply chains: practice vs theory. The International Journal of Logistics Management. 18 (2): 274-293.

Schmoltzi, C., Wallenburg, C. M., 2011. Horizontal cooperations between logistics service providers: motives, structure, performance. International Journal of Physical Distribution \& Logistics Management. 41 (6): 552-576.

Simatupang, T. M., Sridharan, R. 2002. The collaborative supply chain. International Journal of Logistics Management. 13 (1): 15-30.

Simatupang, T. M., Sridharan, R. 2005. An integrative framework for supply chain collaboration. International Journal of Logistics Management. 16 (2): 257-274. 
Skjoett-Larsen, T., Thernøe, C., Andresen, C. 2003. Supply chain collaboration: theoretical perspectives and empirical evidence. International Journal of Physical Distribution and Logistics Management. 33 (6): 531-549.

Spekman R. E., Kamauff, J. W., Myhr, N., 1998. An empirical investigation into supply chain management: a perspective on partnerships. International Journal of Physical Distribution \& Logistics Management. 28 (8): 630-650.

Spekman, R. E., Spear, J., Kamauff, J., 2002. Supply chain competency: learning as a key component. Supply chain management: an international journal. 7 (1): 41-55.

Stank, T. P., Keller, S. B., Daugherty, P. J. 2001. Supply chain collaboration and logistical service performance. Journal of Business Logistics. 22 (1): 29-48.

Todeva, E., Knoke, D. 2005. Strategic alliances and models of collaboration. Management Decision. 43 (1): 123-148.

Tuominen, M. 2004. Channel collaboration and firm value proposition. International Journal of Retail and Distribution Management. 32 (4): 178-189.

Van der Horst, M. R., De Langen, P. W., 2008. Coordination in hinterland transport-chains: a major challenge for the seaport community. Maritime Economics \& Logistics. 10 (1-2): 108-129.

Van der Horst \& Van der Lugt. (2009). Coordination in railway hinterland chains: an institutional analysis. Paper presented at the International Association of Maritime Economists (IAME) conference, Copenhagen, June 2009.

Wallenburg, C. M., Raue, J. S. 2011. Conflict and its governance in horizontal cooperations of logistics service providers. International Journal of Physical Distribution and Logistics Management. 41 (4): 385-400.

Wathne, K. H., Heide, J. B. 2000. Opportunism in interfirm relationships: forms, outcomes, and solutions. Journal of Marketing. 64 (4): 36-51.

Whipple, J. M., Frankel, R. 2000. Strategic alliance success factors. The Journal of Supply Chain Management. 36 (2): 21-28.

Whipple, J. M., Russell, D. 2007. Building supply chain collaboration: a typology of collaborative approaches. The International Journal of Logistics Management. 18 (2): 174-196.

Williamson, O. E. (1975). Markets and Hierarchies: Analysis and Antitrust Implications, The Free Press, New York.

Williamson, O. E. (1985). The Economic Institutions of Capitalism. The Free Press, New York. 
Woodburn, A., 2003. A logistical perspective on the potential for modal shift of freight from road to rail in Great Britain. International Journal of Transport Management. 1 (4): 237245.

$\mathrm{Wu}$, C. 2008. Knowledge creation in a supply chain. Supply chain management: an international journal. 13 (3): 241-250.

Ye, Y., Shen, J. and R. Bergqvist, 2014, High Capacity Transport associated with Pre- and Post- Haulage in Intermodal Road-Rail Transport, Journal of Transportation Technologies, 4 (3): 289-301.

Yin, R. (2009). Case Study Research. Thousand Oaks, CA: Sage. 